Analitika: Jurnal Magister Psikologi UMA, Vol. 10 (2) Desember (2018)

ISSN: 2085-6601 (Print), ISSN: 2502-4590 (Online),

DOI: http://dx.doi.org/10.31289/analitika.v10i2.2125

\title{
ANALITIKA
}

Jurnal Magister Psikologi UMA

Available online http://ojs.uma.ac.id/index.php/ analitika

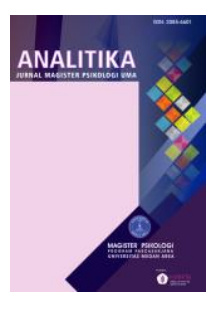

\section{Learning Activities of Students using Developed Innovative Pop-up Book}

\section{Kegiatan Belajar Siswa dengan Mengembangkan Buku Pop-up Inovatif}

\author{
Sri Adelila Sari*1) \& Agung Prawoto ${ }^{2)}$ \\ 1) Fakultas Matematika dan IPA, Universitas Negeri Medan, Indonesia \\ 2) Fakultas Keguruan dan Ilmu Pendidikan, Universitas Syiah Kuala Banda Aceh, Indonesia \\ Diterima: November 2018, disetujui: Desember 2018, dipublish: Desember 2018
}

*Corresponding author: E-mail: adelila@gmail.com

\begin{abstract}
This study was aimed to describe learning activities of students using innovative developed pop-up book on colloids. The development method used was research and development ( $R$ \& D) through ADDIE model. Subjects in this study were thirty one of senior high school students from grade XI, SMAN 4 Banda Aceh which were taken by purposive sampling. Data of students' activities were collected using observation sheet. Besides that, the eligibility of developed pop-up book was measured using questionnaire which was filled by expert validators. Results showed that the eligibility of pop-up book was found to be 73.50 percent belong to the category of decent. In addition, the learning activities were found to be increased from 76.21 to 86.25 percent from first meeting to second meeting, respectively. It concluded that the learning activities of students using developed innovative pop-up book on colloids material were very good.
\end{abstract}

Keywords: Learning Activities, Pop-Up Book, Students

\begin{abstract}
Abstrak
Penelitian ini bertujuan untuk menggambarkan kegiatan belajar siswa menggunakan buku pop-up yang dikembangkan inovatif pada koloid. Metode pengembangan yang digunakan adalah penelitian dan pengembangan (Litbang) melalui model ADDIE. Subjek dalam penelitian ini adalah tiga puluh satu siswa SMA dari kelas XI, SMAN 4 Banda Aceh yang diambil secara purposive sampling. Data kegiatan siswa dikumpulkan menggunakan lembar observasi. Selain itu, kelayakan buku pop-up yang dikembangkan diukur menggunakan kuesioner yang diisi oleh validator ahli. Hasil penelitian menunjukkan bahwa kelayakan buku pop-up ditemukan 73,50 persen termasuk dalam kategori layak. Selain itu, kegiatan belajar ditemukan meningkat dari 76,21 menjadi 86,25 persen dari pertemuan pertama ke pertemuan kedua, masing-masing. Disimpulkan bahwa kegiatan belajar siswa menggunakan buku pop-up inovatif yang dikembangkan pada materi koloid sangat baik.
\end{abstract}

Kata kunci: Kegiatan Belajar, Buku Pop-Up, Siswa

How to Cite: Adelila, S. \& Agung, P. (2018), Learning Activities of Students using Developed Innovative Pop-up Book, Analitika: Jurnal Magister Psikologi UMA, 10 (2): 111 - 117. 


\section{INTRODUCTION}

Student activity plays an important role during the teaching and learning process. It will cause high interaction between teacher and student or student itself. Student activities to be observed include students 'interest and attention to the lessons, the spirit of student learning, responsibility for the learning tasks, the students' pleasure in the tasks assigned by the teacher. If one or more of the above activities are applied to the students, the school will become more dynamic, not boring and really become the center of maximum learning activities and will even smoothen its role as a center and cultural transformation. Proper use of media is a way to improve students' activities. Media is everything physical tools that can present the message and stimulate students to learn (Sadiman, et al., 2005). Retno and Saputro, (2015) stated that learning media is one important factor in improving the quality of teaching in schools. This is because of the demands of efficiency and effectiveness in learning.

Chemistry subjects are subjects which difficult for students because they are abstract and complicated. So that additional information is needed to make the abstract material into concrete and complex become more obvious. Materials that are considered difficult one of them is colloids. Teachers should be smart to develop interesting media for colloids that contain only concepts and are abstract more easily understood by learners. Fun learning and not boring can be implemented by adopting some kind of learning media, such as pop-up books. Pop-up is a book that has moving parts or have 3 dimensional elements and provide interesting story visualization, ranging from display images that can move when the page is opened (Dzuanda, 2013). On the pop-up, the material presented in the form of an interesting picture because there are parts which when opened can move, change or give the impression arises. It is suitable for colloidal material containing abstract concepts and theories. Selection pop-up as a medium of learning in colloids because this material has never been developed. In addition, it also could be increased reading interest of learners. According to Indriana, (2011) the advantages facilitate and accelerate students' understanding of the message presented; can be equipped with colors so as to attract students' attention; and faster and cheaper manufacturing process.

Some learning activities to use the media pop-up undertaken include: (i) listening activities, (ii) visual activities, (iii) writing activities, (iv) oral activities, (v) emotional activities, and (vi) mental activities. In addition to the type of the event, there are two types of activities that are not assessed in the study using the media pop-up is motor activities and drawing activities (Sadiman, et al., 2005). Based on observations in SMA Negeri 4 Banda Aceh, it was found that chemistry learning in the classroom often uses lecture and discussion methods. However, the use of learning media is still less, except power point and textbooks. Interviews were also conducted to a chemistry teacher who stated that the colloid material never used the media, but only used the 
lecture method. Based on this, therefore this study had been interested to be done.

\section{METHODOLOGY}

This research had been conducted in class XI IPA, SMA Negeri 4 Banda Aceh from January to August 2016. The method used was research and development (R \& D) based on ADDIE which included 5 (five) stages, i.e., Analysis, Design, Development, Implementation and Evaluation. Students of class XI IPA1 as the subject of research with the number of 31 (thirty one) students consisted of 14 boys and 17 girls, taken by purposive sampling. The data sources of this research consisted of feasibility of media, which was collected using questionnaire and students' activities which were observed using observation sheet. The categories of pop-up book feasibility and students' activities (Arikunto \& Jabar, 2010) were as follows: (i) 80-100 (very good), 66-79 (good), 56-65 (enough), 46-55 (less), and 0-45 (very bad).

\section{RESULT AND DISCUSSIONS}

This study was first started with the preparation phase, which covered the collection of information about the use of learning media in SMA Negeri 4 Banda Aceh. Information obtained based on observations, interviews from students and teachers. The result found that the students prefer to study if they use of learning media in the form of software and hardware. While interviews with teachers showed that the implementation of learning only use the lecture method, used books, and sometimes using power point and have never learned to use the pop-up book Subsequent analysis, the choice of materials to be used in the study of colloidal material was selected due to it contains complex theories, i.e., colloidal system, colloidal properties, colloid making, and colloid role in everyday life.

\section{Design}

Steps to design the pop-up were as follows: a) The design was formulated. The design contained subject matter, basic competences, learning indicators, the main concept of colloid and exercises. It was created using software program, namely Corel Draw X7. This design included the steps of image selection, color adjustment, preparation of the layout of the pop-up on each page. Media components in the pop-up includes a cover, table of contents, learning guidance, core competences, basic competences to be achieved, content, conclusions, exercises and bibliography. b) The tools and materials were prepared, such as scissors, double-sided tape, cutter, glue fox, pencils, rulers, picture that has been designed using the application Corel Draw $X$, then the image printed on the paper type American drill with A4 size. c) The pictures were cropped. Pictures as objects according to the image pattern was cut and leave 3-5 $\mathrm{cm}$ under the object as a buffer. A folding paper was prepared that could be folded into three, the middle of which was sized with the rest of the paper under the object from 3 to $5 \mathrm{~cm}$ or according to the distance of the object with the background on each page. d) The pictures were pasted. The cut image 
was pasted in accordance with the pattern already created. Paste one end of the buffer with the back of the object using double-sided tape. Paste was done up the above and down on paper pads pop-up neatly. e) The draft of pop-up book was developed. Each page was put together using glue neatly fox. The cover that was printed with the technique of hard cover on the outside was added. The process of designing media pop-up book covers the principles as described by Masna, (2013). There are 3 (three) principle design of media pop-up book, i.e., readiness or motivation, in this media given learning objectives. The second is the principle of center of attention, media pop-up book consists of pictures that aim to attract the attention of students. The third principle is active students, the media pop-up book is not only teachers who can use but students can also participate actively when playing a pop-up book. Based on this, the media in the process of designing a pop-up book should have regard to various aspects that can improve the perfection of media pop-up book.

\section{Development}

Steps to develop the pop-up were as follows: a) Pre design. Assessment of media material in the pop up was done by collecting resources and references as well as pictures associated with colloids materials. References used in the preparation of colloids material was chemistry book 2 for senior high school class XI. The pictures were downloaded from the internet and adapted to colloids material. The pictures and illustrations were intended to clarify the description of the material on the popup book. b) The improvement of popup draft. Draft that had been designed and then compiled into a book by referred to the material sequence based on core competence and basic competences in the syllabus. Sub materials contained: the indicators of the colloidal system, the types of colloidal properties of colloids, manufacture colloids and colloidal role in everyday life.

Fig. 1 shows the developed colloids pop-up book.

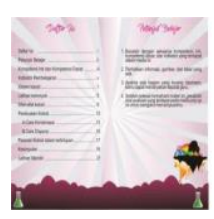

(i)

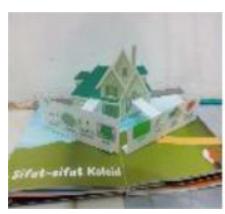

(iv)

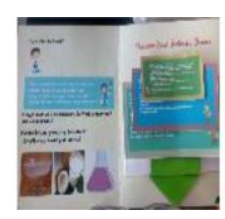

(ii)

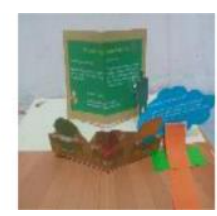

(v)

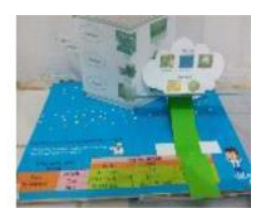

(iii)

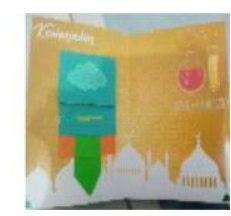

(vi)
Figure 1. Developed Innovative Pop-up Book: (i) Table of content, (ii) page of colloidal definition, (iii) page of the colloidal types, (iv) page of colloidal properties, ( $\mathrm{v}$ ) the role of colloids page, and (vi) the conclusion page

\section{c) The development of assessment instruments. The} validation of pop-up book was assessed using questionnaire sheet and the students' activities were assessed using observation form. d) Validation of popup book. Validation aimed to assess the feasibility of the pop-up book. The feasibility of pop-up book on colloids material obtained from the expert validators. Based on the results 
obtained, feasibility pop-up book was found to be 73.50 percent and classified categories fit for use as a medium of learning. e) Revisions to the pop-up book. The results of the validation showed that the media pop-up book still has shortcomings that need improvement in some parts. The development phase was aimed to produce pop up as decent book. Various stages were done to produce a viable medium, such as revision. Aisha, (2012) stated that the media pop-up book is one of the alternative media with a child learning its potential to attract the attention of children. By displaying a three dimensional and interactive form can provide educational materials to learners in different ways, accompanied with interesting pictures. The use of illustrations, colors, and explanations that are tailored to the local wisdom prevailing in the community so that learners feel more interested in learning the chemistry of colloids matter.

\section{Implementation}

Implementation stage was the stage of the pop-up application. Students learned to use the pop-up in 6 (six) groups consisted of 5-6 people. The division of groups was done randomly. Each group received 1 (one) pop-up which became a source of learning. Students in groups were paid attention to each page and then done the presentation in front of the class. At the end of the meeting, students had to answer the exercise from the pop-up book. At the first of meeting, students did not understand how to use the popup, so that it must explain each step before. However, learning activities at the second meeting were found to be increased. In this stage, teacher did not explain the overall material as in the usual learning. By using pop-up book, it was expected that students could find their own concept and understood it.

\section{Evaluation}

Evaluation phase was the last stage in the development of pop-up. The assessment of the feasibility was done by content and media aspects. In addition, evaluation was also done to observe the learning activities. Evaluation was done after the learning process. The result of validation test of the content was found to the percentage of 71.5. This findings were supported by Khoirunissa, (2014), where chemistry pop-up book was a source of independent study of students. Based on the evaluation results, therefore colloids pop-up book had good results, so that could be used in teaching chemistry in schools.

\section{Learning Activities of Students}

Students were divided into of 6 (six) groups consisting of 5-6 people. There were 6 (six) observers those who observed the activities of students in each group. Some assessed aspects consisted of 6 (six) aspects, i.e., listening activities (the consideration of teacher's description), visual activities (observe pop-up book, writing activities (take note the description of the teacher), mental activities (responding to the results of discussions), oral activities (gave the advice in a group), and emotional activities (focused on learning).The learning process can be seen in Fig. 2. 


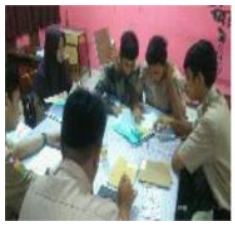

(i)

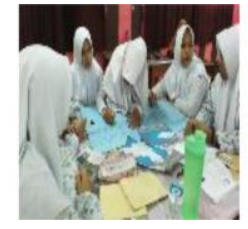

(ii)

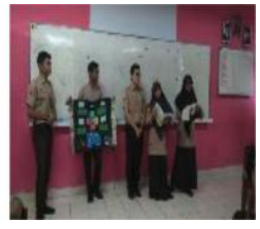

(iii)
Figure 2. The implementation of pop-up on colloids: (i) students observed the pop-up, (ii) the group work prepared the presentation materials, and (iii), students presented the results of group

Based on observations, there were 13 (thirteen) students with very good category of activities, and 12 (twelve) students in good category, the other 6 (six) students in enough category. Overall, percentage of students' activities was equal to 76.21 percent and fallen into good category. Fig. 3 shows the learning activities of students. There was an increase in the activity of students found in studying colloidal material using pop-up book. The highest type of activity observed was visual activities, and the lowest percentage of activities was found to be mental activities. It might be due to the limited time of learning, so that not all students had time in responding the discussion. However, overall students still had good activities because in group discussions some students were appeared to be actively advised and there were some students in the group who were lacked in group discussions. This also might be due to during the learning process taken place, students look very enthusiastic and motivated in following the learning process.

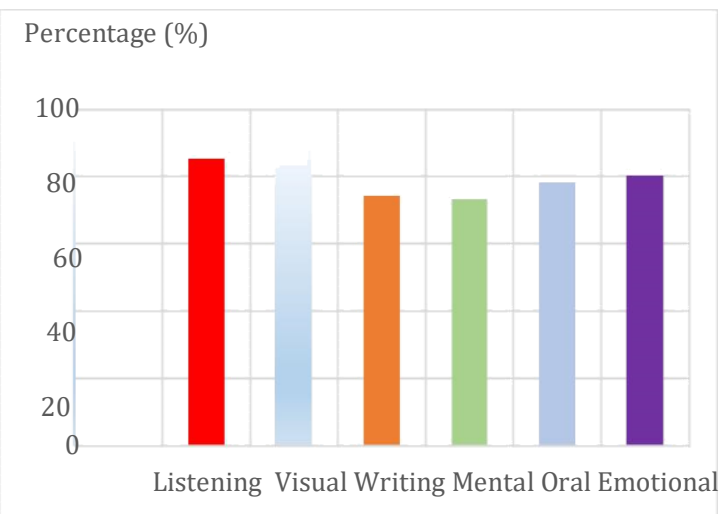

Figure 3. Learning Activities Aspects of Students

\section{CONCLUSIONS}

Learning activities of students when studied using innovative pop-up book in colloids material was increased from first to the second meeting. The percentage of the activities was found to be 76.21 to 86.25 percent, respectively. It might be due to the developed of colloids pop-up book had the eligibility up to 73.50 percent with a decent category and students more enthusiastic and motivated in following the learning process.

\section{REFERENCES}

Aisha. (2012) Pop-up Book Design as Media Education Organization of WWF Indonesia. Inosciences. Vol. 7 No. 2: 8o $-86$

Arikunto, S. \& Jabar, C.S.A. (2010). Evaluation of Education Program. Jakarta: Earth Literacy.

Indriana, D. (2011). Ragam Alat Bantu Media Pengajaran. Yogyakarta: Diva Press.

Khoirunisa, O.R. (2014). Pengembangan Media Chemistry Pop Up Book Materi Perkembangan Teori Atom Sebagai Sumber Belajar Mandiri Peserta Didik Kelas X SMA/MA. Skripsi. Universitas Negeri Yogyakarta.

Masna, A.A. (2013). Fun Story Pop-Up: Media Mendongeng Berbasis Tematik 
Sri Adelila \& Agung Prawoto, Learning Activities of Students using Developed Innovative Pop-up Book

Integratif Guna Membangun Karakter Generasi Emas 2045. Bandung.

Retno, A.T.B. Saputro, S. \& Utami, B. (2015). Development of Learning Media Bulletin In The Form of Hebrew-Based Pocket Handbook Concepts For Classical Chemistry Learning XI Salt Hydrolysis Materials. Journal of Chemical Education (JPK), Vol. 4 No. 2: 74-81.
Sadiman, A.S. Rahardjo, R. Haryono, A. \& Rahardjito. (2005). Understanding Media Education, Development, and Utilization. Jakarta: PT Raja Grafindo Persada.

Dzuanda. (2013). Perancangan Buku Cerita Anak Pop Up Tokoh-Tokoh Wayang Berseri, Seri "Gatot Kaca”. Jurnal Library ITS Undergraduate. 